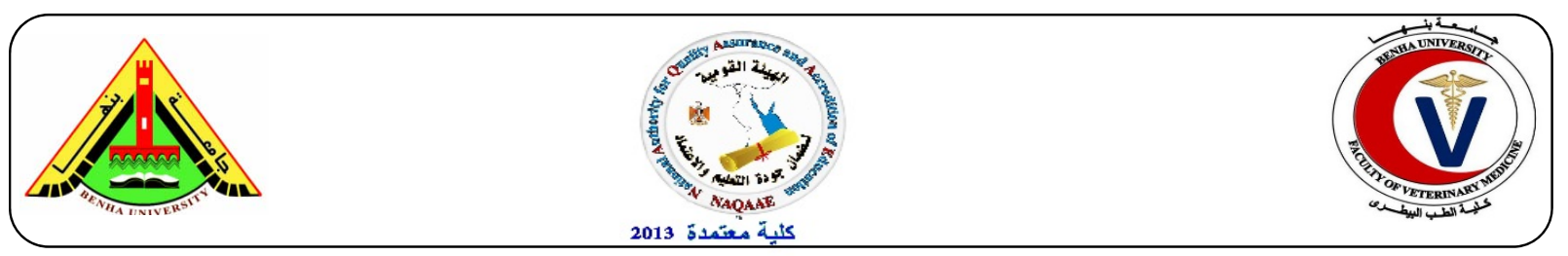

\title{
Bacteriological and molecular studies of garlic effect on some virulence genes of Escherichia coli of chicken origin.
}

\author{
Ahlam, A. Gharib ${ }^{1}$, Mokhtar, A. Sleim ${ }^{2}$, Mohamed, I. Hegazy ${ }^{3}$, Abdel-wahab, A.M. ${ }^{1}$ and Sara, \\ H. Adly ${ }^{2}$. \\ ${ }^{1}$ Microbiology Department, Fac. of Vet. Med., Zagazig Univ., \\ ${ }^{2}$ Animal Health Research Institute (Zagazig branch) \\ ${ }^{3}$ Agricultural Microbiology Department, Fac. of Agr., Zagazig Univ.,
}

\section{A B S T R A C T}

Avian colibacillosis is the most significant infectious bacterial disease of poultry worldwide. Many antimicrobial-resistant Escherichia coli pathogens are increased due to drug overusing in veterinary medicine and animals feed. The objective of this study was to observe the in vitro inhibitory effect of garlic (Allium sativum) as alternative natural agent against Escherichia coli isolates and their virulence genes expression. The antimicrobial effects of aqueous and ethanolic garlic extracts against multidrug-resistant (MDR) E. coli isolates were studied using agar well-diffusion method as well as the minimum inhibitory concentration (MIC) of garlic and consequently their subinhibitory concentration (SIC) (the concentration of garlic that did not inhibit $E$. coli growth after $24 \mathrm{hr}$. incubation at $37^{\circ} \mathrm{C}$ ) were calculated by a modification of broth macrodilution method. The $E$. coli virulence was assessed via mRNA expression of their genes such as increased serum survival (iss), verotoxine (vt2e) and intimin (eaeA) before and after garlic treatment using reverse transcriptase real time PCR. One hundred and thirteen $(46.12 \%)$ of 245 isolates were identified as E. coli that were highly recorded in intestinal samples as $64.60 \%$ followed by liver $24.77 \%$ then heart $10.6 \%$. The most chemotherapeutic resistant 14 E. coli isolates showed high garlic susceptibility rates mainly for aqueous extract and had nine different serotypes, the most predominant one was $\mathrm{O} 146$ of $21.42 \%$. The complete inhibition of and downregulating of eaeA and vt2e genes expression were proved respectively in the E. coli treated isolates with garlic SIC (1\%). In conclusion, the garlic supplementation through feed can reduce infection by E. coli via decrescent their toxin production and may be the adhesion ability to the intestinal mucosa of the host either animal or human.

KEY WORDS: Garlic (Allium sativum)-MIC- E. coli- virulence gene

(http://www.bvmj.bu.edu.eg)

(BVMJ-32(1): 29-40, 2017)

\section{INTRODUCTION}

Avian colibacillosis signs are nonspecific and vary with age, organs involved, and concurrent disease. Young birds dying of acute septicemia have few lesions except for an enlarged, hyperemic liver and spleen with increased fluid in body cavities. Birds that survive septicemia develop subacute fibrinopurulent airsacculitis, pericarditis, perihepatitis, and lymphocytic depletion of the bursa and thymus (unusually pathogenic Salmonellae produce similar lesions in chicks). Although airsacculitis is a classic lesion of colibacillosis. In addition, their sporadic lesions include pneumonia, arthritis, osteomyelitis, peritonitis, and salpingitis (Lutful Kabir, 2010). Diarrhea is a clinical sign of a disease that may have many causes, and E. coli has been frequently implicated as the primary bacterial cause (Yamamoto and Nakazawa, 1997). Diarrhea is an extraordinary common disease with worldwide distribution and diarrhoeagenic $E$. coli is an important bacterium to cause it, the pathogenic strategies of these diarrhoeagenic strains exhibit remarkable variety in causing it (Clarke, 2001). Virulence is the measure of the pathogenicity of an organism. The degree of virulence is related directly to the ability of the organism to cause disease, despite host resistance mechanisms. Virulence factors are produced by a microorganism and evoke disease such as toxins, surface coats that inhibit phagocytosis and surface appendages that bind to the host cells (Peterson, 1996). Bacterial attachment is thought to enhance virulence by promoting colonization of the urinary tract and by attacking tissue. Uropathogenic express several classes of fimbriae-associated adhesins that mediate attachment through specific binding to 
different glycoconjugate receptors (Leffler and Svanborg Ede'n, 1990). The production of Shiga toxins or Verotoxins is one of the defining characteristics of E. coli O157; these toxins are thought to be responsible for the principal manifestations of hemorrhagic colitis (HC) and haemolytic uremic syndrome (HUS) (Paton, 1998). Certain studies have suggested a link between avin pathogenic Escherichia coli (APEC) and human diseases, thus, the enhanced control of avian colibacillosis proved to have benefits to both animal and human health (Ewers et al., 2004). The use of natural compounds has gained significant attention due to increasing concerns about the safety of synthetic chemicals and emerging antibiotic resistance in bacteria (Abee et al., 1995; Salamci et al., 2007). Garlic (Allium sativum) is one of those natural compounds that was seriously investigated over the years. It has been used for centuries to fight infections (Onyeagba et al., 2004). The early Egyptians used it to treat diarrhoea, the ancient Greeks used it to treat intestinal and extra intestinal diseases, while the ancient Japanese and Chinese used it to treat headache, flu, sore throat and fever. In Africa, particularly in Nigeria, it is used to treat abdominal discomfort, diarrhoea, otitis media and respiratory tract infections (Jaber and Al-Mossawi, 2007). Allicin (one of the active principal component of garlic) had been identified as antimicrobial ingredient (Ankri and Mirelman, 1999), which does not exist in garlic until it is crushed or cut; injury to the garlic bulb activates the enzyme allinase, which metabolizes alliin to allicin (Peyman et al., 2013). Allicin showed antibacterial activity primarily by partially inhibiting DNA and protein synthesis then by total inhibition of RNA synthesis as a primary target (Eja et al., 2007; Feldberg et al., 1988). Previous studies reported that exploring herbal plants efficacy on bacterial virulence genes' expression were sparse, for instance, Trans-cinnamaldehyde and clove oil that were evaluated as natural alternative to chemotherapeutics in down-regulation of Salmonella and Aeromonase virulence genes expression in poultry and fish (Abd El-Hamid et al., 2016; Kollanoor-Johny et al., 2012) respectively. IN contrast, there is no studies investigated the similar down-regulated expression effect for the garlic in virulence genes of such $E$. coli.

Therefore, this study was aimed to assess the in vitro antibacterial activity of garlic against $E$. coli as well as to shed spot light upon its efficacy in reducing E. coli infection in chicken (adhesion and toxins production) through reducing some of their virulence gene expression profiles using qRTPCR.

\section{MATERIALS AND METHODS}

\subsection{Samples}

Two hundred and forty five tissue specimens obtained from intestine 119, liver 68 and heart 58 of freshly died and diseased birds that showed signs of diarrhoea and lesions of coli-septicemia (colicystitis and air saculitis) were bacteriologically examined for the presence of $E$. coli. The examined samples were collected randomly from different farms and localities as 140 in El-Sharkia and 105 El-Dakahlia Governorates, Egypt.

\subsection{Garlic extracts}

Fresh garlic bulbs were purchased from a retail store. After its cleaning and sterilization, aqueous and ethanolic extracts were prepared according to the methods of Martha et al. (1998) and Gaherwal et al. (2014) respectively.

\subsection{Isolation and identification of E. coli isolates:}

Classical identification of $E$. coli depends mainly on its growth on MacConkey`s agar plates, streaking on Eosin Methylene Blue (EMB)medium and biochemical examination of its typical colonies by IMVC and TSI (Quinn et al., 2002).

\subsection{Serogrouping of E. coli isolates.}

Serogrouping of pathogenic E. coli isolates was carried out by slide agglutination method using specific polyvalent and monovalent sera of $E$. coli (DENKA SEIKEN CO., LTD., 3-4-2 Nihonbashikaya-cho, Chuo-ku, Tokyo, Japan) and was performed in the Serology Unit, Animal Health Research Institute, Dokki, Giza, Egypt. (Finegold et al., 1978).

\subsection{Antimicrobial susceptibility testing.}

The susceptibility of E. coli isolates were determined by the standard disk diffusion method (Ortez, 2005) against eight antimicrobial agents including colistin $(10 \mu \mathrm{g})$, doxycycline $(30 \mu \mathrm{g})$, amoxicillin+clavulanic acid $(30 \mu \mathrm{g})$, ampicillin $(10 \mu \mathrm{g})$, gentamicin $(10 \mu \mathrm{g})$, spiramycine $(100 \mu \mathrm{g})$, ciprofloxacin $\quad(5 \mu \mathrm{g}), \quad$ and sulfamethoxazole+trimethoprim $(25 \mu \mathrm{g})$ (Oxoid, 1998). By using Agar well-diffusion assay, the antibacterial activity of garlic aqueous extract was tested in different concentrations $(100 \%, 50 \%$ and $25 \%$ against 25 different isolated E. coli (previously showed a MDR by the disk diffusion) according to Srinivasan et al. (2009).

\subsection{Determination of SICs of garlic.}


The MIC as well as SIC of garlic extracts against $E$. coli isolates were determined using a modification of broth macrodilution method according to Kollanoor et al. (2010). Duplicate 50$\mathrm{ml}$ tubes containing $20 \mathrm{ml}$ brain heart infusion broth (BHI) were separately inoculated with $4-5 \times$ $10^{6} \mathrm{CFU} / \mathrm{ml}$ of each E. coli strain. The bacteriological suspensions were distributed in eleven tubs ( $1 \mathrm{ml}$ each). Garlic extract was added with an increment of $0.1 \mathrm{mg} / \mu \mathrm{l}$ each from 0.1 to 1 $\mathrm{mg} / \mu \mathrm{l}$ to the corresponding tubes and incubated at $37^{\circ} \mathrm{C}$ for $24 \mathrm{~h}$. After the incubation, samples were drawn from each tube, diluted (1/10) in sterile PBS (pH 7.2) and plated on TSA plates. The highest concentration of garlic that did not inhibit the bacterial growth after $24 \mathrm{~h}$ of incubation was taken as the SIC.

\subsection{Genotypic detection of the three common virulence genes in E. coli isolates}

Specific primer sequences were used to amplify the three E. coli virulence genes such as increased serum survival (iss), verotoxine (vt2e) and intimin
(eaeA). Each strain of E. coli (either treated or untreated with garlic) was grown in BHI medium with or without SIC of garlic to mid-log phase at $37^{\circ} \mathrm{C}$ (Table 1 ).

\subsubsection{PCR amplification.}

DNA was extracted by ABIO pure genomic DNA extraction kit (Metabion, Germany) according to the manufacturer instructions. PCR amplification was performed with a PTC-100 programmable thermal cycler in a final volume of $25 \mu \mathrm{l}$ consisting of $12.5 \mu \mathrm{l}$ of DreamTaq TM Green Master Mix (2X) (Fermentas, USA), $1 \mu 1$ of each primer, $7 \mu 1$ of template DNA and nucleasefree water up to $25 \mu 1$. Amplified PCR products were electrophoresed on $1.5 \%$ agarose gel in tris acetate EDTA and visualized by UV transilluminator. PCR amplification cycles for $E$. coli strains were illustrated in Table (1) as, initial denaturation step at $95^{\circ} \mathrm{C} / 5$ min for all genes, and final denaturation step was at $72{ }^{\circ} \mathrm{C} / 45 \mathrm{sec}$ in both eaeA and vt2e genes while at $72{ }^{\circ} \mathrm{C} / 30 \mathrm{sec}$ in iss gene.

Table (1): Oligonucleotide primer sequences and cycling protocols used for genotypic identification of $E$. coli virulence genes.

\begin{tabular}{|c|c|c|c|c|}
\hline $\begin{array}{l}\text { Target } \\
\text { gene }\end{array}$ & $\begin{array}{l}\text { Sequence } \\
5^{\prime}-3^{\prime}\end{array}$ & $\begin{array}{l}\text { PCR } \\
\text { amplification } \\
\text { cycles }\end{array}$ & $\begin{array}{l}\text { Product } \\
\text { size } \\
\text { (bp) } \\
\end{array}$ & Reference \\
\hline eaeA & $\begin{array}{l}\text { F : GACCCGGCACAAGCATAAGC } \\
\text { R: CCACCTGCAGCAACAAGAGG }\end{array}$ & $\begin{array}{l}94^{\circ} \mathrm{C} 45 \mathrm{sec} / \\
54^{\circ} \mathrm{C} 45 \mathrm{sec} . / \\
72^{\circ} \mathrm{C} 45 \mathrm{sec} .35\end{array}$ & 384 & Wen-Jie et al. (2008) \\
\hline$v t 2 e$ & $\begin{array}{l}\text { F:CCAGAATGTCAGATAACTGGCAC } \\
\text { R: GCTGAGCACTTTGTAACGGCTG }\end{array}$ & $\begin{array}{l}94^{\circ} \mathrm{C} 45 \mathrm{sec} / \\
57^{\circ} \mathrm{C} 45 \mathrm{sec} / \\
72^{\circ} \mathrm{C} 45 \mathrm{sec} . \quad 35\end{array}$ & 322 & Orlandi et al. (2006) \\
\hline Iss & $\begin{array}{l}\text { F:ATGTTATTTCTGCCGCTG } \\
\text { R:CTATTGTGAGCAATATC }\end{array}$ & $\begin{array}{l}94^{\circ} \mathrm{C} 30 \\
\mathrm{sec} / .54^{\circ} \mathrm{C} 30 \mathrm{sec} . / \\
72^{\circ} \mathrm{C} 30 \mathrm{sec} .\end{array}$ & 266 & Yaguchi et al. (2007) \\
\hline
\end{tabular}

\subsubsection{Semi-quantitative reverse transcriptase real time PCR (RT-PCR)}

Semi-quantitative RT-PCR was performed to study the effect of garlic SIC on the mRNA expression profile of three E. coli virulence genes after RNA isolation and complementary DNA (cDNA) synthesis. Total RNA extraction was performed according to manufacture instructions of QIAamp RNeasy Minikit (Qiagen, Valencia, $\mathrm{cA}$ ). The RNA quantities were evaluated by measuring the optical density at wave lengthes of 230, 260 and 280nm, using Nanodrop technique (Technical Bulletin Nanodrop 2000/2000cThermo Fisher Spectrophotometer) (Rock Land DE, USA) (V1.0 User Manual). This enables the measurement of very highly concentrated samples without the need for dilutions.

Cycling conditions for SYBR green real time $\mathrm{PCR}$ of eae A, vt2e and iss genes were carried out as follows: reverse transcription was performed firstly for each of these genes at $50^{\circ} \mathrm{C}$ for $30 \mathrm{~min}(1 \mathrm{cycle})$ then, primary denaturation at $94^{\circ} \mathrm{C} / 1 \mathrm{~min}$ (1 cycle) . While the amplification process was at 3 steps in 40 cycles: secondary denaturation at $\left(94^{\circ} \mathrm{C} / 45 \mathrm{sec}, 94\right.$ ${ }^{\circ} \mathrm{C} / 30 \mathrm{sec}$ and $\left.94{ }^{\circ} \mathrm{C} / 45 \mathrm{sec}\right)$ annealing at $\left(54^{\circ} \mathrm{C}\right.$ $/ 45 \mathrm{sec}, 57^{\circ} \mathrm{C} / 30 \mathrm{sec}$ and $\left.54{ }^{\circ} \mathrm{C} / 30 \mathrm{sec}\right)$ and extension at $\left(72{ }^{\circ} \mathrm{C} / 45 \mathrm{sec}, 72{ }^{\circ} \mathrm{C} / 30 \mathrm{sec}\right.$ and $72^{\circ} \mathrm{C} /$ $30 \mathrm{sec})$ for eaeA, vt2e and iss respectively. Dissociation curve were generated by a cycle of (94 ${ }^{\circ} \mathrm{C} \backslash 1 \mathrm{~min}, 52{ }^{\circ} \mathrm{C} / 1 \mathrm{~min}$ and $95^{\circ} \mathrm{C} / 30 \mathrm{sec}$ ) for $v t 2 \mathrm{e}$ and $\left(95^{\circ} \mathrm{C} / 1 \mathrm{~min}, 50^{\circ} \mathrm{C} / 1 \mathrm{~min}\right.$ and $\left.95^{\circ} \mathrm{C} / 30 \mathrm{sec}\right)$ for iss genes.

\section{RESULTS}




\subsection{Recovery rate of E. coli isolates.}

One hundred and thirteen (46.12\%) of 245 isolates were identified as $E$. coli that were highly recorded in intestinal samples with a percentage of $64.60 \%(73 / 113)$ followed by liver $24.77 \%$ $(28 / 113)$ then heart $10.6 \%(12 / 113)$, the recovery rate was $61.34 \%, 41.17 \%$ and $20.68 \%$ respectively from organs (/total organ No.) of freshly died and diseased chickens with the total rate of 67(47.85\%) in El-Sharkia and $46(43.80 \%)$ in El-Dakahlia Governorates.

\subsection{Serogrouping of E. coli isolates.}

Nine different serotypes were identified among the selected $14 \mathrm{E}$. coli isolates, and the most predominant one was $\mathrm{O} 146$ with a percentage of $21.42 \%$ followed by O157, O158 and O1 with the same percentage of $14.28 \%$ respectively (Table 2 ).

\subsection{Garlic susceptibility pattern}

It was noted that the E. coli strains showed high sensitivity against the aqueous garlic extract of concentration $100 \%$ represented by the widest inhibition zone $(16-28 \mathrm{~mm})$ followed by $50 \%$ (18-19 $\mathrm{mm})$ and $25 \%(16-17 \mathrm{~mm})$.

\subsection{Garlic SIC against E. coli.}

The tested $E$. coli cultures were inoculated with increment concentrations of crude garlic extract of $0.1 \mathrm{mg} / \mu \mathrm{l}$ each from $0.1-1 \mathrm{mg} / \mu \mathrm{l}$. The results revealed that the SIC of garlic against $E$. coli isolate was $1 \%(0.01 \mathrm{mg} / \mu \mathrm{l})$, where no growth was shown in the tube after that. The initial average of $E$. coli population in the control $(0 \mathrm{mg} / \mu \mathrm{l})$ and garlic treated samples $(0.1 \mathrm{mg} / \mu \mathrm{l})$ was approximately the same about $5 \log 10 \mathrm{CFU} / \mathrm{ml}$. After 24hr. incubation at $37^{\circ} \mathrm{C}$ approximately $8.0 \quad \log 10$ $\mathrm{CFU} / \mathrm{ml}$ of bacteria was recovered from control and treated samples. Thereby, confirming that a fore mentioned concentration of garlic was not inhibitory for E. coli.

\subsection{Antimicrobial resistance phenotype of E. coli isolates.}

The resistance profile of $50 \mathrm{E}$. coli isolates (ElSharkia 37 and El-Dakahlia 13) revealed that, the highest resistance was for ampicillin (84\%) followed by amoxicillin/ clavulanic acid (72\%), sulfamethoxazole/trimethoprim and colistin that was $60 \%$ for each, then spiramycin $(56 \%)$, gentamicin (32\%), doxycycline (24\%), while the lowest one was reported for ciprofloxacin as $16 \%$. Multiple drug resistant strains were detected among most of the E. coli isolates and represented 68\% (34/50).

\subsection{Genotypic identification of the E. coli isolates}

\subsubsection{E. coli virulence genes before and after garlic treatment by PCR amplification}

The obtained results revealed that iss, $v t 2 \mathrm{e}$ and eae A genes were detected in $10,6,5$ of the 14 examined isolates (Table 2) at 384, 322 and $266 \mathrm{bp}$ before garlic treatment and in 10, 4, 0 of the same isolates after garlic treatment respectively (Table 3 and Fig $1,2 \& 3)$.

3.6.2. Effect of the SIC of garlic on expression of E. coli virulence genes by $q R T-P C R$ in different E. coli isolates.

Table (2): Serogroupes and virulence genes of 14 E. coli strains of chicken origin.

\begin{tabular}{|c|c|c|c|c|c|}
\hline \multirow{2}{*}{$\begin{array}{l}\text { Isolates } \\
\text { Code No. }\end{array}$} & \multirow[t]{2}{*}{ Serogroup } & \multirow[t]{2}{*}{$(\%)$} & \multicolumn{3}{|c|}{ virulence genes } \\
\hline & & & iss & $v t 2 \mathrm{e}$ & eae $\mathrm{A}$ \\
\hline $51 \mathrm{H}$ & & & - & + & + \\
\hline $57 \mathrm{H}$ & O146 & 21.42 & - & + & - \\
\hline $80 \mathrm{~L}$ & & & + & - & - \\
\hline $21 \mathrm{I}$ & O158 & 14.28 & + & - & - \\
\hline $62 \mathrm{I}$ & & & - & - & + \\
\hline $8 \mathrm{I}$ & O157 & 14.28 & - & + & + \\
\hline $50 \mathrm{I}$ & & & + & - & - \\
\hline $77 \mathrm{H}$ & $\mathrm{O} 1$ & 14.28 & + & - & - \\
\hline $83 \mathrm{~L}$ & & & + & + & - \\
\hline $3 \mathrm{I}$ & O152 & 7.14 & + & + & + \\
\hline $26 \mathrm{~L}$ & $\mathrm{O} 15$ & 7.14 & + & - & + \\
\hline $37 \mathrm{H}$ & O115 & 7.14 & + & - & - \\
\hline $52 \mathrm{~L}$ & $\mathrm{O} 18$ & 7.14 & + & + & - \\
\hline $97 \mathrm{~L}$ & O126 & 7.14 & + & - & - \\
\hline
\end{tabular}


Table (3): Isolation percentage of E. coli virulence genes of chicken organs using conventional PCR

\begin{tabular}{|c|c|c|c|c|c|c|c|c|}
\hline \multirow{5}{*}{$\begin{array}{l}\text { Virulence } \\
\text { gene (s) }\end{array}$} & \multicolumn{8}{|c|}{ No. $(\%)$ of positive isolates and their virulence genes } \\
\hline & \multicolumn{4}{|c|}{ before garlic treatment } & \multicolumn{4}{|c|}{ after garlic treatment } \\
\hline & Positive & gene & No. $(\%$ & & Positive & gen & No. $(\%$ & \\
\hline & Isolates & intestine & liver & heart & Isolates & intestin & liver & heart \\
\hline & & & & & & & & \\
\hline \multirow[t]{2}{*}{ Iss } & $10 / 14$ & $5 \backslash 5$ & $3 \backslash 5$ & $2 \backslash 4$ & $10 / 14$ & $5 \backslash 5$ & $3 \backslash 5$ & $2 \backslash 4$ \\
\hline & $(71.42)$ & $(100)$ & $(60)$ & $(50)$ & $(71.42)$ & $(100)$ & $(60)$ & $(50)$ \\
\hline \multirow[t]{2}{*}{$v t 2 \mathrm{e}$} & $6 / 14$ & $4 \backslash 5$ & $2 \backslash 5$ & 0 & $4 / 14$ & $3 \backslash 5$ & $1 \backslash 5$ & 0 \\
\hline & $(42.85)$ & (80) & (40) & $(0.0)$ & (28.57) & (60) & (20) & $(0.0)$ \\
\hline \multirow[t]{2}{*}{ eaeA } & $5 / 14$ & $2 \backslash 5$ & $1 \backslash 5$ & $2 \backslash 4$ & $0 / 14$ & 0 & 0 & 0 \\
\hline & $(35.71)$ & (40) & (20) & $(50)$ & $(0.00)$ & $(0.0)$ & $(0.0)$ & $(0.0)$ \\
\hline Sum & 21 & 11 & 6 & 4 & 14 & 8 & 4 & 2 \\
\hline
\end{tabular}

A)

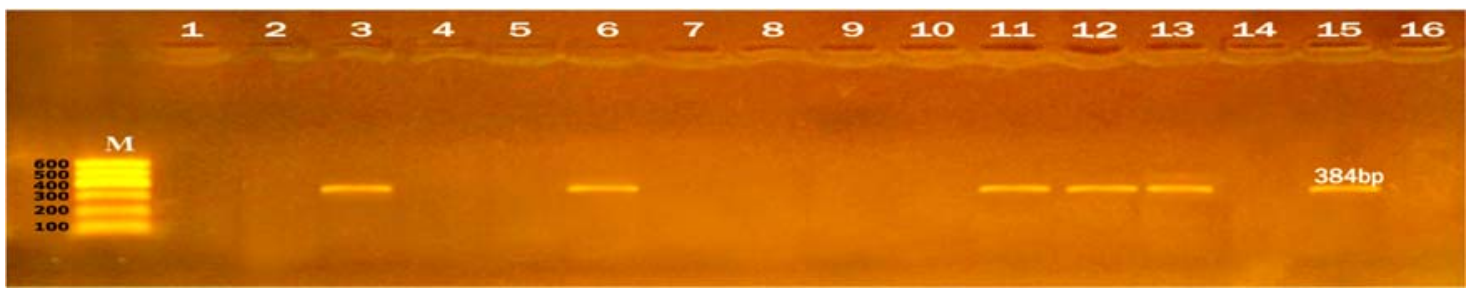

B)

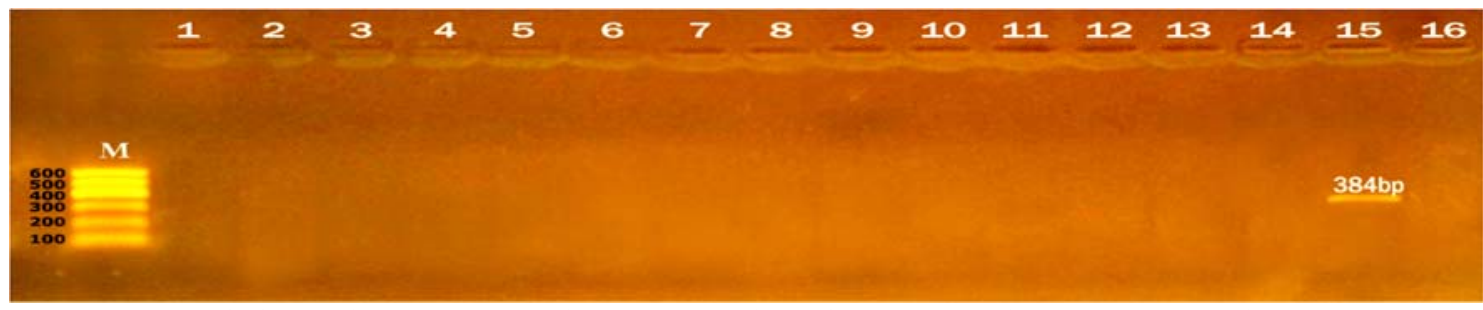

Fig (1) Agarose gel electrophoresis pattern showing typical amplification products of eaeA virulence gene in uniplex PCR for the isolated fourteen E. coli strains. M: 100 bp DNA ladder "Marker". A) Before treatment, lanes 3,6, 11,12,13 showed amplification at 384 bp for 5 eaeA gene, B) After treatment, all lanes had no eaeA gene. Lanes 15: control positive and lane16: control negative,

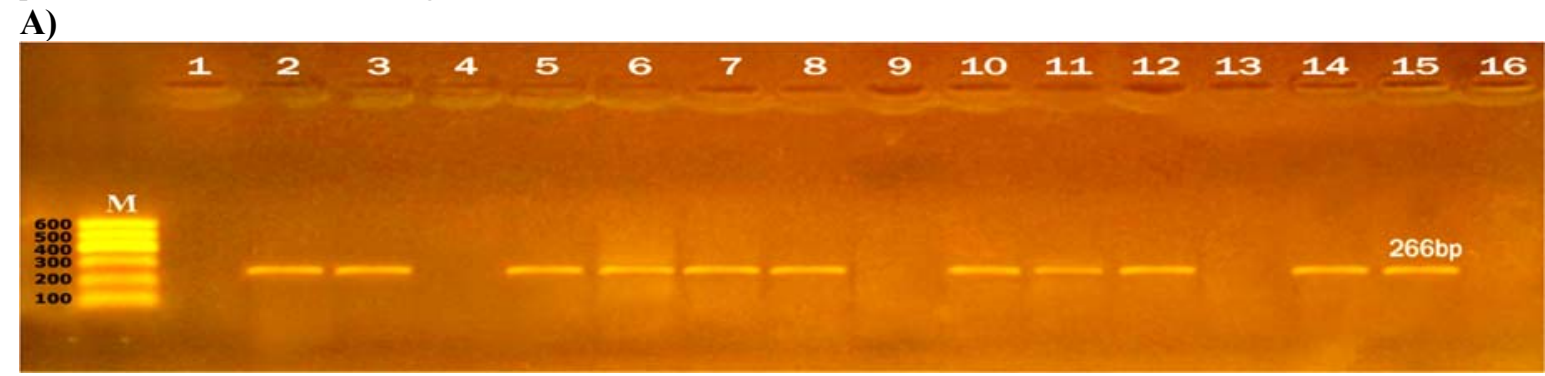

B)

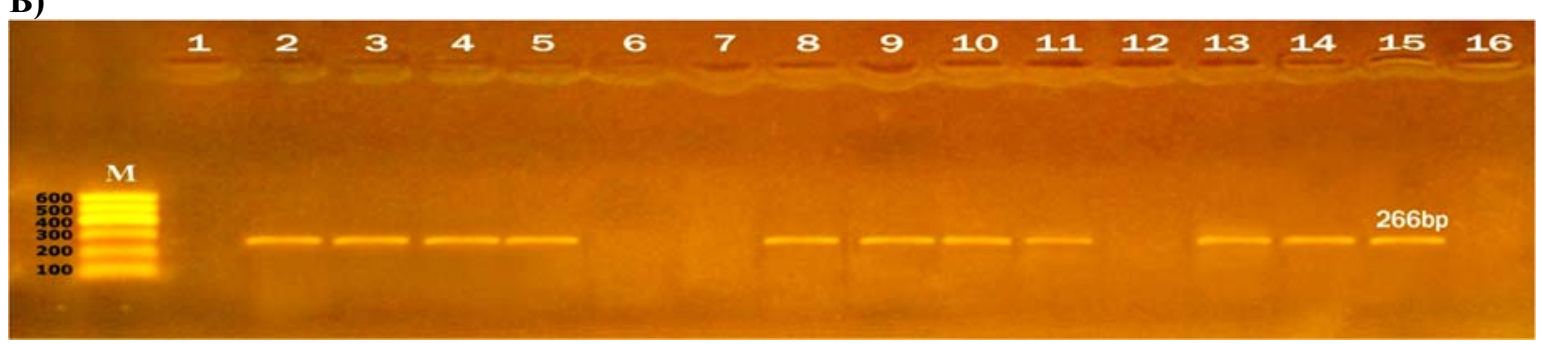

Fig (2) Agarose gel electrophoresis pattern showing typical amplification products of iss virulence gene in uniplex PCR for the isolated fourteen $E$. coli strains. M: $100 \mathrm{bp}$ DNA ladder "Marker". A) Before treatment, lanes 2,3,5,6,7,8,10,11,12 and 14 showed amplification at 266 bp for iss gene, B) After treatment, lanes 2,3,4,5,8,9,10,11,13 and 14 of ten E. coli isolates had 266 band of iss virulence genes. Lanes 15: control positive and lane16: control negative, 
A)

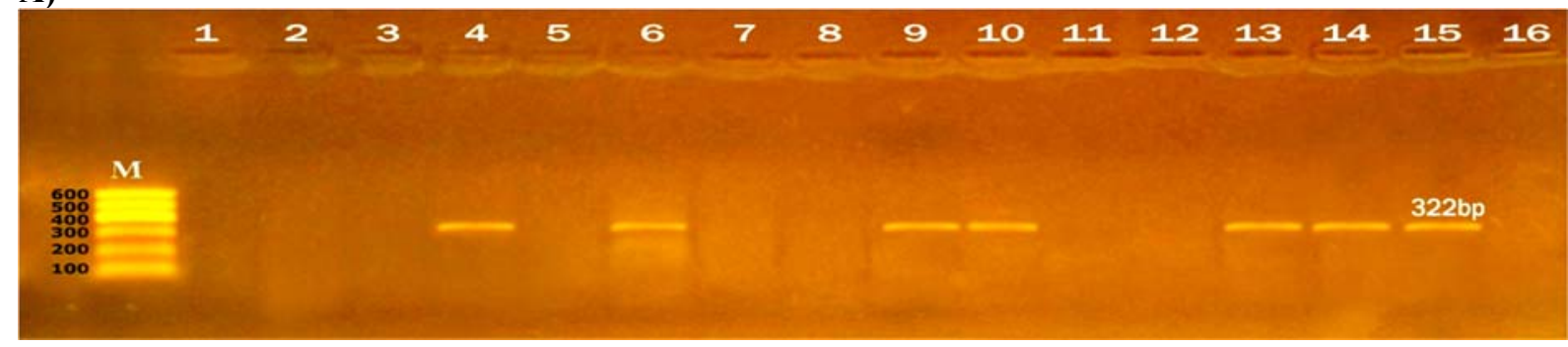

B)

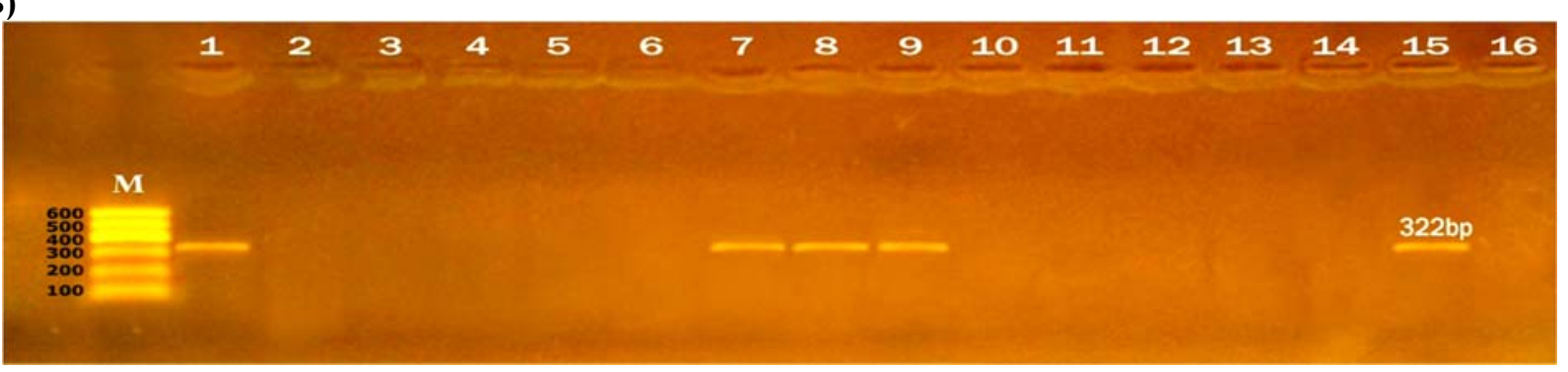

Fig (3) Agarose gel electrophoresis pattern showing typical amplification products of vt2e virulence gene in uniplex PCR for the isolated fourteen E. coli strains. M: 100 bp DNA ladder "Marker" A) Before treatment, lanes 4,6,9,10,13and 14 showed amplification at 322 bp for $6 v t 2 \mathrm{e}$ gene, B) After treatment, lanes 1,7,8 and 9 of four E. coli isolates had 322 bp bands of vt2e virulence genes. Lanes 15: control positive and lane16: control negative,

Table (4): Data sheet of q RT-rtPCR showing E. coli vt2e (in two isolates) and iss genes, before and after garlic treatment.

\begin{tabular}{lll}
\hline \multicolumn{1}{c}{ Well Name } & $\mathrm{C}_{\mathrm{t}}$ & Tm Product \\
\hline$v t 2 \mathrm{e}$ (isolate 8I) (untreated with garlic) & 18.60 & 80.55 \\
$v t 2 \mathrm{e}$ (isolate 8I) (treated with garlic) & 19.42 & 80.55 \\
$v t 2 \mathrm{e}$ (isolate 3I) (untreated with garlic) & 21.66 & 80.55 \\
$v t 2 \mathrm{e}$ (isolate 3I) (treated with garlic) & 21.63 & 80.55 \\
Iss (untreated with garlic) & 14.36 & 79.72 \\
Iss (treated with garlic) & 14.42 & 79.72 \\
\hline
\end{tabular}

$\mathrm{C}(\mathrm{t})$ : Threshold cycle. Tm Product: the peak value of curve referring to second annealing temperature.

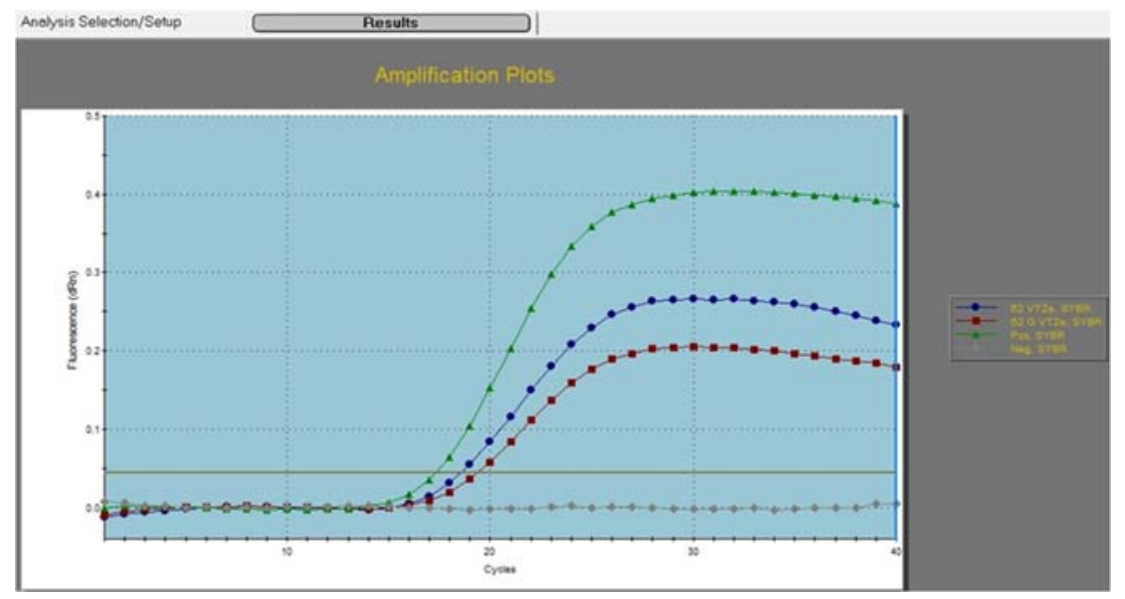

Fig (4A): 


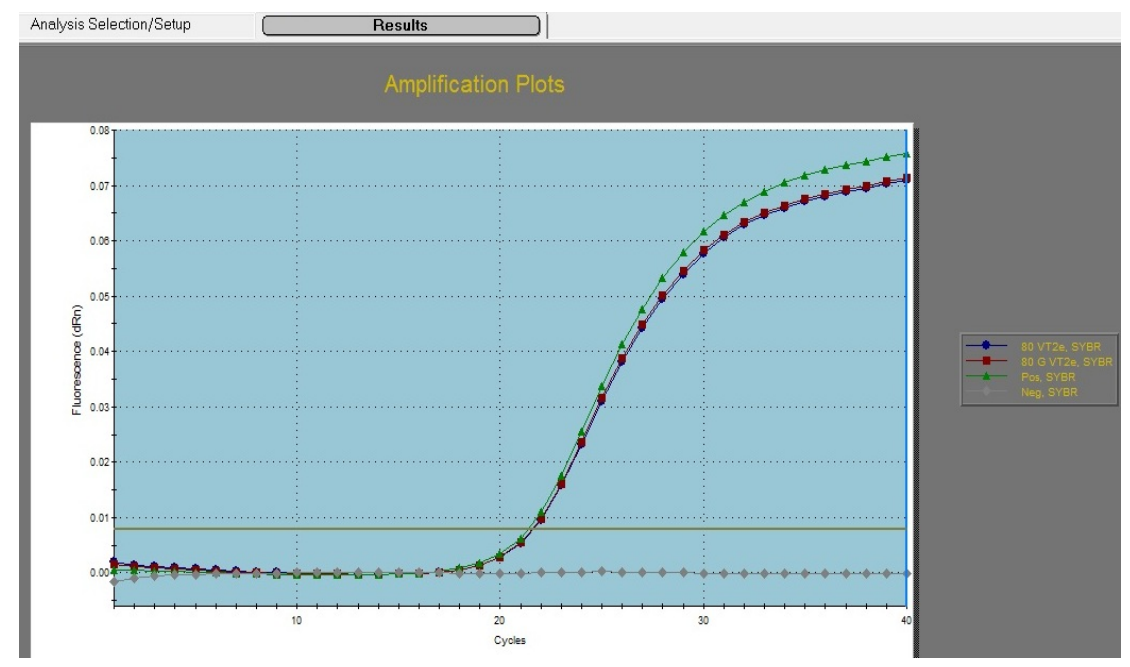

Fig (4B):

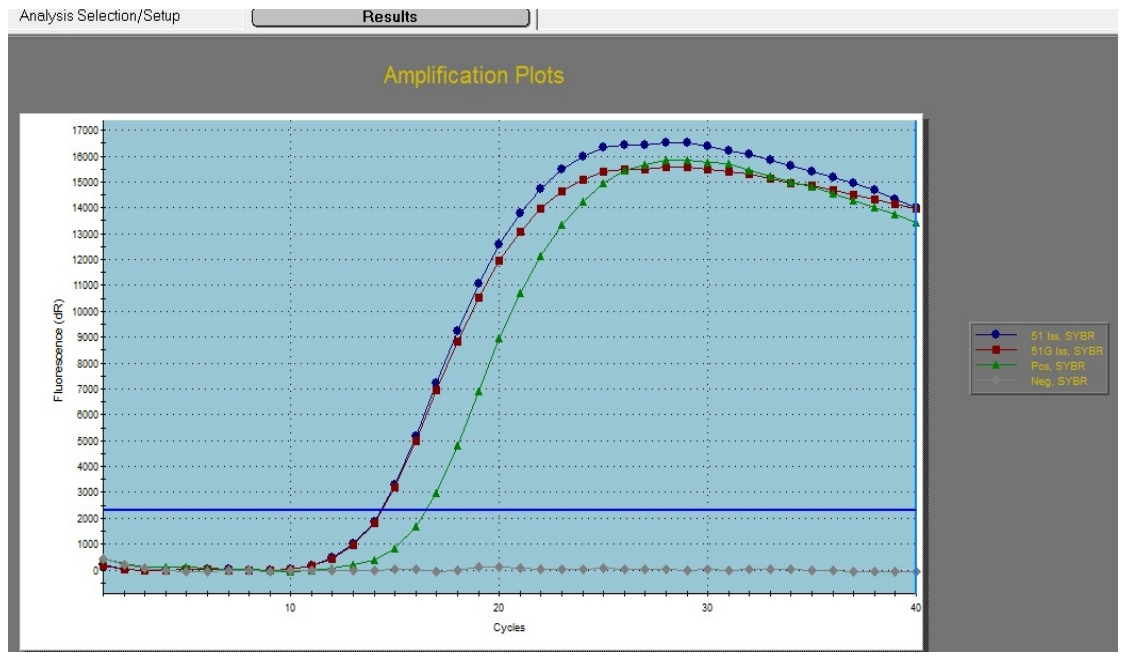

Fig (4C) A amplification curves of qRT-PCR for semi-quantitative detection of E.coli vt2e and iss genes expression before and after garlic treatment. A) $v t 2 \mathrm{e}$ (isolate $8 \mathrm{I}$ ). B) $v t 2 \mathrm{e}$ (isolate $3 \mathrm{I}$ ). C) iss.

A Positive control

$\because \bullet$ Sample untreated with garlic

There was a clear difference in the amount of cDNA detected after gene expression assessment of $E$. coli strains before and after treatment with garlic extract. The absorbance of DNA in the standard samples was measured using ultra-violet spectrophotometer at $260 \mathrm{~nm}$ and the $v t 2 \mathrm{e}$ (isolate 8I) product was relatively quantitated as increased in samples untreated with garlic than those treated, at $C_{t}$ value of 18.60 and 19.42 , respectively.

The $v t 2 \mathrm{e}$ (isolate $3 \mathrm{I}$ ) and iss products were relatively quantitated and revealed nearly the same result for the samples untreated and treated with garlic. The results of real time PCR of $v t 2 e(8 \mathrm{I})$, $v t 2 e(3 \mathrm{I})$ and iss are shown in Table (4) Fig 4 A, B and $\mathrm{C}$ respectively). From Table (4), the relative quantity estimation of $E$. coli vt2e in isolate (8I)
Negative control

Sample treated with garlic proved that its concentration was reduced after garlic treatment $\left(C_{t}\right.$ value was increased) (Fig. 4A), which reflect the decreasing effect of garlic on mRNA expression of this gene. The abovementioned data, proved that the garlic downregulated E. coli virulence genes expression.

\section{DISCUSSION}

Avian pathogenic E. coli (APEC) is responsible for extra intestinal diseases, called colibacillosis in avian species, which is considered as one of the principal causes of morbidity and mortality in poultry with high economic losses (Janßen et al., 2001; Omer et al., 2010). Regarding to the incidence of the infection with $E$. coli in specimens 
of intestine, liver and heart of freshly died and diseased poultry that was $64.6 \%, 24.7 \%$ and $10.6 \%$ respectively. These results were nearly similar to those detected by Sharada et al. (2010) and Wafaa (2012) who isolated E. coli from diseased chicken with total recovery rate $44.6 \%$ and $46,6 \%$ respectively. Higher incidence rates were previously recorded by Nashwa et al. (2010) and Shymaa (2013) who recorded E. coli with a percentage of $75 \%$ for each. On the other hand a lower incidence (15.8\%) was detected by Momtaz et al. (2012). Regarding to the incidence of the infection with E. coli in specimens of intestine, liver and heart of poultry that was $64.6 \%, 24.7 \%$ and $10.6 \%$ respectively. In Egypt, a higher incidence of $E$. coli than that mentioned in the current research were documented previously in several studies in both liver and heart, $(36 \%$ and 14.3\%) (Heba et al., 2012), (28.1\% and 15\%) (Ashraf et al., 2014) respectively and (20\%) in heart only (Hassanin et al., 2014).

The 14 E. coli isolates recovered from broilers and layers suffering from diarrhoea were serotyped. The results showed that $\mathrm{O} 146$ was the most predominant serotype with a percentage of $21.4 \%$, followed by O158, O157 and O1 (14.2\%), the remained isolates were serotyped as $\mathrm{O} 152$, O115, O18, O15 and O126, one isolate for each serotype $(7.1 \%)$. These results are in line with those recorded by Azucena et al. (2013) who stated that the most common E. coli serotype in avian colibacillosis was O146 serotype and Rezk et al. (2010) who detected E. coli O146 and O125 serogroups in diseased chickens collected from different localities in Ismailia Governorate. On the contrary to the currant results in Sharkia Province, the most obtained serotype was $\mathrm{O} 78$ from avian colibacillosis (Ammar et al., 2011) and O125 (AlAjimi, 2011). Moreover isolation of serogroup O157 is alarming that it was associated with outbreaks of sporadic cases of haemorrhagiccolites and haemolytic uremic syndrome in human (Gould et al., 2009) this serogroupe had been previously isolated from diseased chickens by Rezk et al. (2010) suggesting that poultry may act as a reservoir for $E$. coli and possess a zoonotic risk for human (Hussein et al., 2013). In fact, in avian species, $\mathrm{O} 1$ and $\mathrm{O} 15$ are reported to be common sources of colibacillosis in Italy and could be classified as avian pathogenic strains (Antonio et al., 2007). In our antimicrobial susceptibility test that was performed on $50 \mathrm{E}$. coli isolates, the results indicated that the isolates were resistant to ampicillin, amoxicillin/ clavulanic acid, colistin, sulphamethoxazole/ trimethoprime and spiramycin (84\%, 72\%, 60\%, 60\% and 56\%, respectively) while they were susceptible to doxycycline, ciprofloxacin and gentamicin $(60 \%, 50 \%$ and $44 \%$, respectively). Similar results were detected by Salehi and Bonab (2006) who illustrated that $E$. coli isolates were sensitive to Ciprofloxacin followed by gentamicin. Olatoye et al. (2012) Ezzeldeen et al. (2013) and Fyre and Jackson (2013), showed that the tested E. coli samples were resistant to amoxicillin/clavulanic acid and ampicillin, while were sensitive to ciprofloxacin

The results of the present study are similar to those of garlic aqueous extract examined by Indu et al. (2006) Srinivasan et al. (2009) and Fahad et al. (2013) who mentioned that garlic aqueous extract was active against $E$. coli. with inhibition zone of 30 $\mathrm{mm}, 33 \mathrm{~mm}$, and $26 \mathrm{~mm}$ for the three researchers respectively. The inhibitory effect of garlic was found to be due to allicin (Ankri and Mirelman, 1999). In contrary, Packia Lekshmi et al. (2015) mentioned that garlic aqueous extract had a little antibacterial activity against $E$. coli. The minimum inhibitory concentration of garlic aqueous extract was found to be $(20 \mathrm{mg} / \mathrm{ml})(0.02 \mathrm{mg} / \mu \mathrm{l})$. The current detected results were similar to that detected on ethanolic extract of garlic by Musa et al. (2013) who found that the MIC was $20 \mathrm{mg} / \mathrm{ml}$. Lower incidences of garlic MIC against E. coli than that mentioned in the present study were documented previously in several studies for aqueous extract as $3.2 \mathrm{mg} \backslash \mathrm{ml}$ (Iwalokun et al., 2004). Higher results were detected on other plants as that detected by Kollanoor-Johny et al. (2012) who found that the minimum inhibitory concentration of trans-cinnamaldehyde (TC) extract against Salmonella was $(200 \mathrm{mg} \backslash \mathrm{ml})$.

From the results, it was noted that the PCR products of the obtained virulence genes of $E$. coli isolates from chicken gave characteristic bands at 266, 322 and 384bp for iss, vt2 and eaeA virulence genes, respectively, and that iss gene was the most prevalent virulence gene $(71.42 \%)$, so it represents an additional virulence marker playing a role in the pathogenesis of poultry colibacillosis. These results are in accordance to Orlandi et al. (2006) Yaguchi et al. (2007) and Wen-Jie et al. (2008). Higher incidence of iss virulence gene, obtained by Ewers et al. (2004), and Moemen et al. (2014) as $(82.7 \%),(73.8 \%)$ and $(72.2 \%)$ respectively and add that the iss gene (the anti-complement) one of the most important genes that help in pathogenisity and virulence of APEC and is the most dominant gene isolated from chicken suffered from diarrhoea (Soon-Gu et al., 2008).

After treatment of $E$. coli isolates with garlic extract the virulence genes expression gave different results by RT-rtPCR, showed that 10 isolates (71.42\%) expressed iss, the same as before treatment, while 4 (28.6) of 6 expressed $v t 2$, finally eaeA cannot be expressed in all examined isolates which affirm that garlic extract can completely 
inhibit or downregulate the expression of virulence genes on E. coli mRNA. The forementioned results go hand in hand with that of different plant extracts on other genus by Kollanoor-Johny et al. (2012) who found that trans-cinnamaldehyde (TC) and eugenol (EG) reduced the motility and invasive abilities of $S$. Enteritidis and downregulated expression of the motility genes ( $f l h C$ and $m o t A)$ and invasion genes (hilA, hilD, and $i n v F)$. And on the same genus of Escherchia Dorota et al. (2012) who detected that the Urtica dioica extracts significantly reduced the motility of the E. coli rods and biofilm activity and other extracts of Vaccinium vitis-idaea decreased the bacterial survival and virulence factors involved in tissue colonization and biofilm formation of the uropathogenic Escherichia coli.

\section{CONCLUSION}

After treatment of the E. coli isolates with garlic aqueous extract SIC, the reverse transcriptase cPCR (RT-PCR) technique showed that the expression profile of $v t 2 \mathrm{e}$ virulence gene was decreased while the eaeA gene was disappeared completely in the representative isolates. That may reflect the garlic efficacy on transcription of the E. coli virulence genes. And relative quantitative (semi-quantitative) reverse transcriptase real time PCR (qRT-PCR) analysis confirmed the excellent role of garlic (previously detected by RT-cPCR) focused on the inhibition and down-regulation of $E$. coli virulence genes expression mainly eaeA and $v t 2 \mathrm{e}$ gene. Therefore, the garlic supplementation through feed can reduce infection by $E$. coli via decrescent their toxin production and may be the adhesion ability to the intestinal mucosa of the host either animal or human.

\section{REFERENCES}

Abd El-Hamid, M.I., Abd El-Aziz, N.K., Ali, H.A., 2016. Protective potency of clove oil and its transcriptional down-regulation of Aeromonas sobria virulence genes in African catfish (Clarias gariepinus L.). Cell Mol Biol (Noisy-le-grand) 62, 49-54.

Abee, T., Krockel, L., Hill, C., 1995. Bacteriocins: modes of action and potentials in food preservation and control of food poisoning. Int J Food Microbiol 28, 169-185.

Al-Ajimi, A.m. 2011. Escherichia coli isolated from broiler farms with special references to virulence genes of isolated strainsM.V.Sci., Zag.Uni.

Ammar, A.M., Norhan, K.A., Yousreya, H.M., Abd El-Aziz, E., F. , 2011. Advanced studies on diagnosis of single M. Gallisepticum infection and combined with $\mathrm{E}$. coli in chickens. Zag.Vet. J. 39, 110-114.

Ankri, S., Mirelman, D., 1999. Antimicrobial properties of allicin from garlic. Microbes Infect 1, 125-129.

Antonio, C., Elena, C., Davide, G., Donato, P., Patrizia, B., Evelyn, C., Giordano, B., Silvia, T., 2007. Avian Pathogenic Escherichia coli in Audouin gulls(Larus audouinii).Could they affectthe survival of the bird colonies? Ital. J. Anim. Sci. 23, 317-320.

Ashraf, A.A.E.T., Maarouf, A., Samir, A., Abd El Aal, A., El Hofy, F., I., El Mougy, E.A., 2014. Detection of some virulence genes of Avian Pathogenic E. coli by Polymerase Chain Reaction. Ben.Vet. Med. J 26, 159176.

Azucena, M., Alexandra, H., Cecilia, L., Ghizlane, D., Rosalia, M., Julia, M., Pita, P., Alonso, L., María, I.B., Jesús E. Blanco, Miguel, B., Jorge, B., 2013. Characteristics of the Shigatoxin producing enteroaggregat Escherichia coli O104:H4 German outbreak strain and of STEC strainsisolated in Spain. International Microbiology 14, 121-141.

Clarke, S.C., 2001. Diarrhoeagenic Escherichia coli--an emerging problem? Diagn Microbiol Infect Dis 41, 93-98.

Dorota, W., Alicja, Z.K., Anna, S.-Ł., Marta, K., Dorota, T.-G., 2012. Medicinal plants extracts affect virulence factors expression and biofilm formation by the uropathogenic Escherichia coli Published online 2012 Aug 23.

Eja, M.E., Asikong, B.E., Abriba, C., Arikpo, G.E., Anwan, E.E., Enyi-Idoh, K.H., 2007. Acomparative assessment of the antimicrobial effects of garlic (Alliumsativum) and antibiotics on diarrheagenic organisms. Southeast Asian J Trop Med Public Health 38, 343-348.

Ewers, C., Janssen, T., Kiessling, S., Philipp, H.C., Wieler, L.H., 2004. Molecular epidemiology of avian pathogenic Escherichia coli (APEC) isolated from colisepticemiae in poultry. Vet Microbiol. 104, 91-101.

Ezzeldeen, N.A., Al Amary, K.F., Abdelmonem, M.A., El-Moez, S.I., Abd el Aziz, M.F., 2013. Genotyping characterization of E. coli Egyptian isolates with special reference to drug resistance genes.

Fahad, A.M., Ahmed, A., Amani, A., Diehl, T.A., 2013. The inhibitory effects of garlic extract and its fractions against some Enterobacteriaceae $\mathrm{sp}$ isolated from 
sprouted Mung bean. Int. J. Curr. Microbiol. App. Sci. 2, 104-115.

Feldberg, R.S., Chang, S.C., Kotik, A.N., Nadler, M., Neuwirth, Z., Sundstrom, D.C., Thompson, N.H., 1988. In vitro mechanism of inhibition of bacterial cell growth by allicin. Antimicrob Agents Chemother 32, 1763-1768.

Finegold, S.M., Martin, W.J., Scott, E.G., 1978. Bailey and Scott's Diagnostic Microbiology, 5th ed. The C.V. Mosby Company, Taipey, Taiwan.

Fyre, J., Jackson, C., 2013. Genetic mechanisms of antimicrobial resistance identified in Salmonella enterica, Escherichia coli and Enteroccocus spp. isolated from U.S. food Front. in Microbiol. 4, 1-22.

Gaherwal, S., Johar, F., Wast, N., Prakash, M., 2014. Antibacterial activities of Allium sativum against Escherichia coli, Salmonella Ser. Typhi and Staphylococcus aureus. International Journal of Microbiological Research 5, 19-22.

Gould, L.H., Mody, R.K., Ong, K.L., Clogher, P., Cronquist, A.B., Garman, K.N., Lathrop, S., Medus, C., Spina, N.L., Webb, T.H., White, P.L., Wymore, K., Gierke, R.E., Mahon, B.E., Griffin, P.M., 2009. Increased recognition of non-O157 Shiga toxinproducing Escherichia coli infections in the United States during 2000-2010: epidemiologic features and comparison with E. coli O157 infections. Food borne Pathog Dis. 10, 453-460.

Hassanin, F.S., Salem, A.M., Shorbagy, E.M., Kholy, R.L., 2014. Traditional and recent techniques for detection of Escherichia coli in fresh chicken cuts and giblets. Ben. Vet. Med. J 26, 21-29.

Heba, R., Abd El-Aziz, S., Mohamed, R., 2012. Incidence of E. coli in chickens and ducks in different governorates in Egypt. 1st Conf. of Anim. Health Res. Inst. Assoc., 420 - 426.

Hussein, A.H., Ghanem, I.A., Eid, A.A., Ali, M.A., Sherwood, J.S., Li, G., Nolan, L.K., Lougue, C.M., 2013. Molecular and phenotypic characterization of Escherichia coli isolated from broiler chichen flocksin Egypt. Avian Dis. J. 57, 602-611.

Indu, M., Hatha, A., Abirosh C., Harsha, U., Vivekanandan, G., 2006. Antimicrobial activity of some of the south-indian spices against serotypesof Escherichia coli, salmonella, listeria monocytogenes and aeromonas hydrophila. Brazilian journal of microbiology 37, 153-158.
Iwalokun, B.A., Ogunledun, A., Ogbolu, D.O., Bamiro, S.B., Jimi-Omojola, J., 2004. In vitro antimicrobial properties of aqueous garlic extract against multidrug-resistant bacteria and Candida species from Nigeria. J Med Food 7, 327-333.

Jaber, M.A., Al-Mossawi, A., 2007. Susceptibility of some multiple resistant bacteria to garlic extract. Afr. J. Biotechnol. 6, 771-776.

Janßen, T., Schwarz, C., Preikschat, P., Voss, M., Philipp, H.C., Wielser, L.H., 2001. Virulence-associated genes in avian pathogenic Escherichia coli (APEC) isolated from internal organs of poultry having died from colibacillosis. Int. J. Med. Microbiol 291, 371-378.

Kollanoor-Johny, A., Mattson, T., Baskaran, S.A., Amalaradjou, M.A., Babapoor, S., March, B., Valipe, S., Darre, M., Hoagland, T., Schreiber, D., Khan, M.I., Donoghue, A., Donoghue, D., Venkitanarayanan, K., 2012. Reduction of Salmonella enterica serovar enteritidis colonization in 20-day-old broiler chickens by the plant-derived compounds trans-cinnamaldehyde and eugenol. Appl Environ Microbiol 78, 2981-2987.

Kollanoor, J.A., Hoagland, T.A., Venkitanarayanan, K., 2010. Effect of subinhibitory concentrations of plantderived molecules in increasing the sensitivity of multidrug-resistant Salmonella enterica serovar Typhimurium DT104 to antibiotics. Food borne Pathog. Dis. 7, 1165-1170.

Leffler, H., Svanborg Ede'n, C., 1990. Chemical identification of a glycosphingolipid receptor for Escherichia coli attaching to human urinary tract epithelial cells and agglutinating human erythrocytes. FEMS Microbiol Lett 8, 127-134.

Lutful Kabir, S.M., 2010. Avian Colibacillosis and Salmonellosis: A Closer Look at Epidemiology, Pathogenesis, Diagnosis, Control and Public Health Concerns. Int J Environ Res Public Health 7, 89-114.

Martha, T., Majed, A.A., Tanuja, B., Jassim, M.A., Mohammed, A., Muslim, A., 1998. Effect of aqueous extract of onion and garlic on the liver and lung of rats. J. Ethnopharmacol. 61, 91-99.

Moemen, A.M., Mostafa, A., Elshimaa, R., 2014. Virulence Genes Content and Antimicrobial Resistance in Escherichia coli from Broiler Chickens. 6, 189-195.

Momtaz, H., Rahimi, E., Moshkelani, S., 2012. Molecular detection of antimicrobial resistance genes in E. coliisolated from 
slaughtered commercial chickens in Iran. Veterinarni Medicina. J. 57, 193-197.

Musa, O.A., David, O.A., Ganiyu, P., Oyeyiola, C., 2013. In-vitroSensitivity of Selected Enteric Bacteria to Extracts of Allium sativum. Sci Biol. J. 5, 183-188.

Nashwa, A.E., Mohamed, K.F., Nahla, A.H., 2010. Characterization of surface proteins of $\mathrm{E}$. coli isolated from different Egyptian sources. Inter. J of Microbiol. 1, 147-161.

Olatoye, I.O., Amosun, E.A., Ogundipe, G.A.T., 2012. Multidrug Resistant Escherichia coli O157 Contamination of Beef and Chicken in Municipal Abattoirs of Southwest Nigeria. Nat. Sci. 10, 125-132.

Omer, M.M., Abusalab, S.M., Gumaa, M.M., Mulla, S.A., Omer, E.A., Jeddah, I.E., AlHassan, A.M., Hussein, M.A., Ahmed, A.M., 2010. Outbreak of colibacillosis among broiler and layer flocks in intensive and semi intensive poultry farms in Kassala State, Eastern Sudan. Asian J Poultry Sci 4, 173-181.

Onyeagba, R.A., Ugbogu, O.C., Okeke, C.U., Iroakasi, O., 2004. Studies on the antimicrobial effects of garlic (Allium sativum Linn), ginger (Zingiber officinale Roscoe) and lime (Citrus aurantifolia Linn). Afr. J. Biotechnol. 3, 552-554.

Orlandi, P.P., Magalhaes, G.F., Matos, N.B., Silva, T., Penatti, M., Nogueira, P.A., Silva, L.H., 2006. Etiology of diarrheal infections in children of Porto Velho (Rondonia, Western Amazon region, Brazil). Braz J Med Biol Res 39, 507-517.

Ortez, H.J., 2005. Test Methods, Disk diffusion testing. In: Manual of antimicrobial susceptibility testing, Coyle, B.M. American Society for Microbiology, Washington DC.

Oxoid, 1998. The oxoid manual of culture media. 8th Ed. Oxoid, Limited, Basingstoke, Hampshire, England pathotypes. Appl. Environ. Microbiol. J. 66, 4926-4934.

Packia Lekshmi, N.C.J., Viveka, S., Jeeva, S., Raja Brindha, J., 2015. Efficacy of crude extracts of Allium sativum and Allium cepa against human pathogens. Advances in Applied Science Research 6, 72-78.

Paton, J.C., 1998. Detection and characterization of shiga toxigenic Escherichia coli by using multiplex PCR assays for stx1, stx2, eaeA, enterohaemorrhagic E. coli hlyA, rfbO111 and rfbO157. J Clin Microbiol. 36, 598-602.

Peterson, J.W., 1996. Medical Microbiology, 4th ed. Samuel Baron, Bacterial Pathogenesis.

Peyman, M., Surush, M., Milad, M., Shahin, A., Shadi, S., 2013. Therapeutic Uses and
Pharmacological Properties of Garlic, Shallot, and Their Biologically Active Compounds Iran. J Basic Med Sci 16, 10311048.

Quinn, P.J., Markey, B.K., Carter, M.E., Donnelly, W.J.C., Leonard, F.C., 2002. Veterinary Microbiology and Microbial Diseases. Blackwell Scientific Publications, Oxford, London.

Rezk, M.M., Enany, M.E., Hanafy, M.S., 2010. Relationship between O-Serogroup, Virulence and Plasmid Profile in Escherichia Coli Isolated from Diseased Chickens. Journal of Food Safety 30, 679698.

Salamci, E., Kordali, S., Kotan, R., Cakir, A., Kaya, Y., 2007. Chemical compositions, antimicrobial and herbicidal effects of essential oils isolated from Turkish Tanacetum aucheranum and Tanacetum chiliophyllum var. chiliophyllum. Biochemical Systematics and Ecology 35, 569-581.

Salehi, T.Z., Bonab, S.F., 2006. Antibiotics susceptibility pattern of Escherichia coli strains isolated from chickens withcolisepticemia in Tabriz Province, Iran. Department of microbiology and immunology, Faculty of VeterinaryMedicine, Tehran University. International Journal of Poultry Science 5, 677-684.

Sharada, R., Ruban, S.W., Thiyageeswaran, M., 2010. Isolation, characterization and antibiotic resistance pattern of Escherichia coli isolated from poultry. AmericanEurasian J. Sci. Res. 5, 18-22.

Shymaa, H.A.M. 2013. Some Advanced Studies on avian pathogenic E. coli in broiler chickens at Sharkia GovernorateM.V.Sc., Zagazig Univ.

Soon-Gu, K., Se-Yeoun, C., Eun-Ju, C., Bokyung, K., Hee-Jong, S., Hyung-Kwan, J., 2008. Epidemiological Prevalence of Avian Pathogenic Escherichia coli Differentiated by Multiplex PCR fromCommercial Chickensand Hatchery in Korea. Journal of Bacteriology and Virology 38, 179-188.

Srinivasan, D., Sangeetha, S., Lakshmana, p., 2009. In vitro Antibacterial Activity and Stability of Garlic Extract at Different $\mathrm{pH}$ and Temperature. Electronic Journal of Biology 5, 5-10.

Wafaa, M.A.G. 2012. Occurrence of antibiotic resistance genes E. coli serotypes isolated from broilersM.V. Sc., Zagazig Univ. 
Wen-Jie, J., Zhi-Ming, Z., Yong-Zhi, Z., Ai-Jian, Q., Hong-Xia, S., Yue-Long, L., Jiao, W., Qian-Qian, W., 2008. Distribution of virulence-associated genes of avian pathogenic Escherichia coli isolates in China. Agricultural Sciences in China 7, 1511-1515.

Yaguchi, K., Ogitani, T., Osawa, R., Kawano, M., Kokumai, N., Kaneshige, T., Noro, T., Masubuchi, K., Shimizu, Y., 2007.
Virulence factors of avian pathogenic Escherichia coli strains isolated from chickens with colisepticemia in Japan. Avian Dis 51, 656-662.

Yamamoto, T., Nakazawa, M., 1997. Detection and sequences of enteroaggregative Escherichia coli heat stable enterotoxin 1 gene in ETEC strains isolated from piglets and calves with diarrhea. J. Clin. Microbiol. $35,223-227$. 